\title{
LEPTOSPIROSIS CONTROL ON AN INTENSIVE RAISING PIG FARM
}

\author{
TEŠIĆ M*, ŽUGIĆ GORDANA**, KLJAJIĆ $\mathrm{R}^{\star \star *}$, TAJDIĆ NADA*, STOJILJKOVIĆ LJ****,

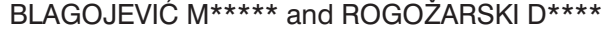

\begin{abstract}
*Faculty of Veterinary Medicine, Belgrade; ** Hemofarm Group, Hemofarm International Animal

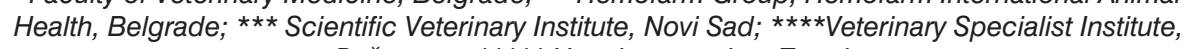
Požarevac, ${ }^{* * * \star *}$ Veterinary station, Topola
\end{abstract}

(Received 17. January 2005)

Leptospirosis is an infective disease which represents serious health and economic problems in pig raising. The disease is caused by bacteria from genus Leptospira interrogans, which has over 250 serotypes and is isolated from most animal species and also from humans in almost every country in the world. In farm conditions the disease is seldom manifested as a clinically apparent illness. More often is manifested as reduced conception rate, increased abortion rate and increased birth of dead and non-vital piglets. The leptospirosis control and eradication program was made for a state owned farm with a capacity of about 1500 sows and over 30000 fattened animals per year. The farm had an on going endemic leptospirosis infection and subsequent progressive economic losses. We detected 29,80\% seropositive sows and gilts, in which serotypes pomona and icterhaemorrhagiae were isolated. Serologic examination of blood was performed again affter program implemenatation, and no positive animals were found, while production and economic results were improved. The control of Leptospirosis and the eradication program for a five-year period were based on detailed quantification of economics losses. Using cost-benefit analysis the necessary inputs and planned outputs were defined, and program evalution was made on the basis of net present value and benefit/cost ratio.

Key words: leptospirosis, economic losses, control program, cost-benefit analysis

\section{INTRODUCTION}

Leptospirosis is common for both humans and animals and has also an zoonotic disposition, because it is transmitted from animals to humans. The disease is caused by bacteria belonging to Leptospira which has over 250 serotypes and is isolated from most animal species and also from humans in almost every country in the world (Hadson, 1978; Kariv et al., 2001). Some authors consider small rodents, especially Mus genus, as a primary sources of 
leptospirosis infection for domestic and wild animals. Leptospirosis is transmitted to animals and humans indirectly by water, food and objects contaminated with infected urine (Zaharija et al., 1964; Webster et al., 1995; Vukićević, 1995; Žugić, 2000). The disease is seldom manifested as a clinically apparent illness with lethal consequences, but more often as reproductive disorders reflected as reduced conception, increased abortions and increased birth of dead and non-vital piglets.

During the sixth and seventh decade of the last century leptospirosis in Serbia was only of endemic importance. It most often emerged in deltas of large rivers with high levels of underground waters which extremely favor leptospirosis preservation (Vićentijević, 1964; Marjanov, 1970). Nevertheless, a well organized veterinary service, persistent and systematic serological diagnostics of breeding animals (sows, gilts and boars), the implementation of necessary preventive measures and control of breeding gilts made state farms become disease-free. On private farms the disease persisted, but with a significantly lesser incidence. With the beginning of last decade the economic crisis emerged in Serbia with a fast worsening of conditions for hog rising (Tešić et al., 2002). The consequence of the general economic crisis in the country was the worsening of the epidemiologic situation. Exception from systematic breeding stock health control (serologic diagnostics, rodent control and disinfection) and the impossibility of animal identification and market control have led to the occurrence of leptospirosis on some state farms. On these farms, abortions and birth of dead and non-vital piglets appeared, with increased economic losses, which have reached up to $20 \%$ depending on the observed time period (Žugić, 2000). On the studied farms, worsening of the epidemiologic situation and increased economic losses demanded the development of a consistent leptospirosis control and a effective eradication program. After identification of causes and quantification of economic losses, in agreement with the farm management, the determination of necessary inputs and outputs was made and financial funds for leptospirosis the development of a control program were provided. Cost-benefit analysis was used for the development of the program and the time horizon for program implementation was determined to five years 1999 to 2003 (Hurne et Dijkhuizen, 1997; Tešić et al., 2003a). After this period the results were compared to the control group, i.e. period until 1998.

\section{MATERIAL AND METHODS}

Our investigation was performed on a pig farm with a complete reproductive production cycle and with a productive capacity of about 1500 gilts and 30000 fattened animals per year. The farm is located in an leptospirosis endemic area which has for more than a decade suffered serious health and economic consequences due to the disease. Basic evidence, as well as veterinary reports on health conditions of the herd in the period from 1998 to 2003, were used as the main data source for analysis of economic losses. Data from the starting year of the analyzed period were used as the control group and results from the final year of the implementation of the leptospirosis control program as the experimental group. Economic losses were calculated per year on the basis of the following 
factors: number of abortions per year, actual number of weaned piglets aged 30 days and $6.5 \mathrm{~kg}$ body weight and the price of $1.5 €$ per $\mathrm{kg}$ of live piglets (Tešić, 1995).

For serological diagnostics of leptospirosis we sampled blood from sows, gilts and boars. Blood was sampled twice: in 1998, before the program was implementated (control group) and in 2003 (experimental group). A total of 604 samples were taken, that is 151 per each sampling. In both groups blood was sampled twice with an interval of two months between sampling. Blood was sampled in $10 \%$ of breeding animals, according to the Regulations for control and eradication of leptospirosis. Selection of animals for sampling was random. Five $\mathrm{ml}$ of venous blood was sampled in sterile test tubes by punction of $v$. cava cranialis. Every test tube was marked with a serial number of corresponding to the animal. Sampled blood was kept on room temperature for 24 hours, than refrigerated at $4^{\circ} \mathrm{C}$ for 24 hours and finally frozen on $-20^{\circ} \mathrm{C}$ until serological testing. For serological testing we used the microagglutination technique (MAT). Serological diagnostics was performed in two stages: in the first leptospira antibodies were detected in the sera and in the second antibody titers in the sera were determined. A control was set for every isolated serotype (pomona and icterohaemorhagiae), which consisted of saline and a culture of corresponding serotype. The reaction was read by dark field microscopy with a magnification of 160 times. The number of live reactive leptospiras in the fileld was marked as follows: $100 \%$ of agglutinated leptospiras - 4+, about $75 \%-3+$, about $50 \%-2+$, and less than $50 \%-1+(\mathrm{OIE}, 1996)$.

Considering the condition on the farm, for leptospirosis eradication we used a consistent program and carried out systematic measures following technological standards, in accordance to the current regulations (Off. Bull. Yu 43/86, 6/88). The leptospirosis control program was based on cost-benefit analysis (CBA). CBA was used for the calculation of average annual income due to reduced mortality, reduced abortions, reduced birth of non-vital piglets, and food savings and also on average annual expenses due to diagnostics, treatment, disinfection and rodent control. After determination and quantification of inputs and outputs the single price for each element was taken and by multiplication of elements and prices, their values and realization dynamics through the five-year period were determined (Table 2.). Because CBA is a dynamic method, nominal values were transformed to present values by discounting (Đorđević, 1987). Net present value (NPV) and benefit-cost ratio (RBC) were used as criteria for the program evaluation (Horst et al., 1999; Rushton et al., 1999; Tešić et al., 2003a). Effects of program implementation after five years were compared to the results of the control group attained in 1998.

\section{RESULTS}

Serological examination of the blood samples in the control group was performed at the end of 1998. in 10\% of breeding animals. During the first examination of the blood $34.44 \%$ of the samples were positive and $25.17 \%$ were positive in the second examination. During first sampling, serotype L. pomona 
was determined in $76.92 \%$ of seropositive animals, and serotype L. icterohaemorrhagiae in $23.08 \%$, while during the second sampling serotypes L. pomona and L. icterohaemorrhagiae were detected in $57.89 \%$ and $42.11 \%$ respectively (Table 1.). Statistically significant difference was found in of positive animals during first and second sampling $(p<0.01)$ in the frequency of $L$. pomona serotype between samplings $(p<0.05)$, while no significant difference was found in the prevalence of serotype $L$. icterohaemorrhaigae between samplings $(p<0.05)$. Out of total number of seropositive animals, gilts made the largest portion $(70.00 \%)$, than sows $(28.89 \%)$, while the boars made the smallest portion $(1.11 \%)$. Serotype L. pomona was detected in a larger percentage $(68.89 \%)$ than the serotype L. icterohaemorrhagiae (31.11\%). In gilts, serotype L. pomona was found in $73.00 \%$ of cases, in sows in $57.69 \%$ and in all cases in boars, while serotype $L$. icterohaemorrhagiae was in gilts and sows in $27.00 \%$ and $42.31 \%$ respectively. In both samplings the antibody titer was in the range from 1:30 to 1 : 10000. In first sampling most of the animals with L. pomona (35\%) and L. icterohaemorrhagiae serotype $(50 \%)$ had the antibody titer of $1: 300$. In the second sampling the most of the animals with serotype $L$. pomona $(31.82 \%)$ had a titer of 1:1000 and with serotype $L$. icterohaemorrhagiae $(37.50 \%)$ had a titer of $1: 100$.

Table 1. Leptospirosis prevalence and serotype frequencies

\begin{tabular}{|c|c|c|c|c|c|c|}
\hline \multirow{2}{*}{$\begin{array}{c}\text { Group } \\
\text { Sampling }\end{array}$} & \multicolumn{2}{|c|}{ Samples } & \multicolumn{2}{c|}{ Seropositive heads } & \multicolumn{2}{c|}{ Serotype } \\
\cline { 2 - 7 } & $\mathrm{N}$ & $\%$ & $\mathrm{~N}$ & $\%$ & pomona & Icterohaem. \\
\hline $\mathrm{K}_{1}$ & 151 & 9.99 & $52^{\star *}$ & 34.44 & $40^{\star}$ & 12 \\
\hline $\mathrm{K}_{2}$ & 151 & 10.03 & 38 & 25.17 & 22 & 16 \\
\hline Total $\mathrm{K}_{12}$ & 302 & 10.01 & 90 & 29.80 & 62 & 28 \\
\hline
\end{tabular}

${ }^{*} \mathrm{p}<0.05 ;{ }^{* *} \mathrm{p}<0.01$

Total expense of the leptospirosis control program for the five-year period was $104403.80 €$, being greatest in the first year (46.44\%) with consecutive reduction to $11.69 \%$ in the last year. During the experimental period, the largest part in expenses was for serological diagnostics (45.52\%), than treatment (23.62\%), rodent control (13.41\%) and disinfection (17.45\%) (table 2). Expected benefit of leptospirosis control program realization on a farm is $166020 €$ for a five-year period, with the smallest participation of the first year $(12,46 \%)$ in total benefit with yearly increase during the observed period. Out of all determined elements which influence profit increased reduction of birth of non-vital piglets had the largest partcipation $64.40 \%$ food savings were $27.11 \%$, abortion reduction $5.85 \%$ and death reduction $2.64 \%$. 
Acta Veterinaria (Beograd), Vol. 55. No. 4, 335-344, 2005.

Tešić $\mathrm{M}$ et al. Leptospirosis control on an intensive raising pig farm

Table 2. Cost and benefit dynamics and structure during program realization

\begin{tabular}{|c|c|c|c|c|}
\hline \multicolumn{5}{|c|}{ a) Cost } \\
\hline Total & $\begin{array}{c}\text { Blood } \\
\text { diagnostics }\end{array}$ & Treatment & $\begin{array}{l}\text { Rodent } \\
\text { Control }\end{array}$ & Disinfection \\
\hline $\begin{array}{c}104403.80 \\
100.00\end{array}$ & 47524.61 & 24660.18 & 14000.55 & 18218.46 \\
\hline & 45.52 & 23.62 & 13.41 & 17.45 \\
\hline \multicolumn{5}{|c|}{ b) Benefit } \\
\hline Total & $\begin{array}{l}\text { Abortions } \\
\text { reduction }\end{array}$ & $\begin{array}{l}\text { Non-vital } \\
\text { piglets }\end{array}$ & $\begin{array}{c}\text { Death } \\
\text { reduction }\end{array}$ & $\begin{array}{l}\text { Food } \\
\text { Savings }\end{array}$ \\
\hline 166020.00 & 9712.17 & 106916.88 & 4382.93 & 45008.02 \\
\hline 100.00 & 5.85 & 64.40 & 2.64 & 27.11 \\
\hline
\end{tabular}

Evaluation of the economical justification of the control program is shown in table 3. Total present value is positive at an interest rate of $8 \%$ and expected benefit is $129430.98 €$, with expenses of $88176.34 €$, but NPV is $41254,64 €$. RBC was 1.47 and shows an expected benefit of $47 \%$. In the first year of the program implementation NPV is negative but increasing in the next period.

Table 3. Net present value for whole period

\begin{tabular}{|c|c|c|c|}
\hline \multirow{2}{*}{ Year } & $\begin{array}{c}\text { Disc. } \\
\text { factor }\end{array}$ & \multicolumn{2}{|c|}{ Present value, $€$} \\
\hline & & Benefit & Expenses \\
\hline 1 & 0.9259 & 20676 & 48479 \\
\hline 2 & 0.8573 & 31476 & 15753 \\
\hline 3 & 0.7938 & 31476 & 15753 \\
\hline 4 & 0.7350 & 41196 & 12210 \\
\hline 5 & 0.6806 & 41196 & 12210 \\
\hline \hline Total PV & - & 129430.98 & 88176.34 \\
\hline NPV & - & 41254.64 \\
\hline RBC & - & \multicolumn{3}{|c|}{1.47} \\
\hline
\end{tabular}

Effects of program implementation are shown in table 4. In the experimental group no animals were positive on $L$. interrogans, while in the control group $29.80 \%$ of samples were positive. Production in the experimental group was greatly improved. The number of farrowings and live piglets per litter was improved by $17 \%$ and $4.5 \%$ respectively and the number of total abortions was reduced by $85(79 \%)$, as well as the number of non-vital piglets and abortions per 
litter by $0.61(55 \%)$ and $0.25(69 \%)$. Economic losses in the experimental group after program implementation were reduced for about $50 \%$, which yields $20218.87 €$ on the farm level, or $14.67 €$ per sow and $8.38 €$ per litter.

Table 4. Production and economic results on the farm after program implementation

\begin{tabular}{|c|l|c|c|c|}
\hline \multirow{2}{*}{ Run } & \multirow{2}{*}{ Variable } & \multicolumn{2}{|c|}{ Groups } & \multirow{2}{*}{$\begin{array}{c}\text { Difference } \\
\text { Ex-K }\end{array}$} \\
\cline { 3 - 4 } & & Ex-2003 & K-1998 & 9.30 \\
\hline \hline 1. & Average number of sows & 1497.90 & 1488.60 & 497 \\
\hline 2. & Number of farrowings & 3340 & 2843 & -85 \\
\hline 3. & Number of abortions & 35 & 120 & 0.43 \\
\hline 4. & Live born piglets & 9.96 & 9.53 & -0.61 \\
\hline 5. & Non-vital piglets & 0.51 & 1.12 & -0.25 \\
\hline 6. & Aborted piglets & 0.11 & 0.36 & \\
\hline 7. & Economic losses, $€$ & & & -20218.87 \\
& - total & 20208.94 & 41027.81 & -14.07 \\
& - per sow & 13.49 & 27.56 & -8.38 \\
\hline 8. & Blood sampling & 3.05 & 14.43 & 0 \\
\hline 9. & Seropositive animals & - & 304 & -90 \\
\hline 10. & Prevalence, \% & - & 29.80 & -29.80 \\
\hline
\end{tabular}

\section{DISCUSSION}

Leptospirosis in pigs is a significant economic and epidemiologic problem in the development of pig raising. Leptospirosis emerges endemically, in some circumstance as limited epidemics. During the second half of the last century leptospirosis in Serbia was present on areas close to large rivers (Danube and Morava) and in the plains (Vojvodina and Mačva), where pig raising took place in the traditional, extensive manner. In Serbia, most often diagnosed serotypes of pig leptospirosis are L. pomona, L. icterohaemorrhagiae and L. canicola. The disease was more present in domestic pig breeds than in white purebred pigs. Investigations have shown a higher prevalence of leptospirosis in private farms compared with state farms. According to Zaharija et Todorović (1964) the percentage of infected pigs on private farms was $82.28 \%$, Vićentijević (1964) gives a value of $44.00 \%$ and Trifunović (1982) from $31.34 \%$ to $73.64 \%$, while on state farms infection spread according to Galić (1967) was 7.62\%, Marjanov et Dujin (1969) found $25.42 \%$, Trifunović (1982) from $11.19 \%$ to $52.33 \%$ and Žugić (2000) from $24.44 \%$ to $25.17 \%$. In the human population in Serbia $9.28 \%$ all leptospirosis cases were caused by serotype $L$. icterohaemorrhagiae and in $52 \%$ of cases the 
infective agent was serotype L.pomona whose main host is the pig (Vukićević 1995).

During the first examination of the control group $34.44 \%$ of tested animals were seropositive. At the time of the second sampling $25,17 \%$ were seropositive. Serotype L. pomona was detected in $68.89 \%$ and serotype $L$. icterohaemorrhagiae in $31.11 \%$ of all cases. Statistically significant difference was found in the number of positive cases between two samplings $(p<.01)$ and also in percentage of detected serotype $L$. pomona $(p<0.05)$, while no significant difference was found between percentage of detected serotype L. icterohaemorrhagiae $(p>0.05)$. The most frequent category was gilts. In both serotypes the most frequent antibody titer was 1:300 (L. pomona $29.03 \%$, L. icterohaemorrhagiae $39.29 \%$ ) which indicates a chronic course of the disease. Authors showed that serotype L. pomona has the highest frequency, while serotype $L$. icterohaemorrhagiae is found less frequently. In Serbia, Trifunović (1982) found serotype L. pomona in $97.61 \%$ and serotype L. icterohaemorrhagiae in $1.62 \%$ of all positive pigs, Rogožarski et al. (1994) found serotype L. pomona in $86.20 \%$ of cases. Zamora et al. (1976) in Chile found serotype L. pomona in $35.50 \%$ of cases, while in Bulgaria Šerkov et al. (1976) found only serotype L. pomona in piglets $(35.40 \%)$, sows $(31.83 \%)$ and gilts $(8.31 \%)$. Similar results as ours regarding antibody titers were presented Harrington (1995), Marjanov and Dujin (1969), Higgins and Cayouette (1997), Clark et al. (1980), Trifunović (1982), Rogožarski et al. (1994) and Boquist et al. (2002).

Authors who investigated pig leptospirosis agree that rodents are the main source and vector of this disease. Animals and humans get infected mostly through the environment contaminated by infected urine, as these bacteria are mainly located in the urinary tract of rats (Vukićević, 1995). Taking into account farm location, type and worn-out equipment, biological and reproductive characteristics of rats and their constant presence, lack of funding for carrying out systematic rodent control, evident damage of installations, walls and floors, it is no wonder that the disease is permanently present on the farm. For that reason the development of leptospirosis control and eradication program is considered justified from the economical and epidemiological point of view. During program development all the necessary activities which should be carried out according to the appropriate legislation and technological parameters were clearly defined (Off. Bull. Yu), as well as the financial effects expected from the implemented program. A time period of five years for program implementation was established using CBA.

Quantification of economic losses caused by leptospirosis on pig farms in Serbia was not studied sufficiently. So far investigations of this disease were purely epidemiological, and therefore results were presented as natural losses such as birth of dead or non-vital piglets, reduction of conception and abortions in sows (Marjanov, 1970; Popović et Galić 1979; Trifunović, 1982; Tešić, 1995). Considering that leptospirosis on a farm can cause more severe indirect than direct losses the increase in number of abortions of sows and gilts and birth of non-vital piglets rises serious suspicion for the appearance of this disease. In her investigation, Žugić (2000) found average annual losses on a farm of 326.892,00 
Yugoslav dinars (YUD), or 84.63 YUD per litter, and Marjanov and Dujin (1969) quantifiet average economic losses on a farm with constant presence of leptospirosis between 10.30 and $15.70 \%$ of annual income. Economic justification of leptospirosis control program on the farm is based on NPC and RBC. Positive NPV of $41.254,64 €$ and RBC higher than 1 are indicators that the program should be implemented during 5-year period. As a result of program implementation, evident improvement in production and economic results in experimental group (i.e. in year 2003) was recorded. In experimental group no L. interrogans seropositive animals were found, contrary to control group where the prevalence was $29.80 \%$. Mean number of abortions was reduced by 3.5 times and piglet losses (non-vital and aborted piglets) by one piglet per litter. Considering the financial effects, the farm has achieved a profit of $20218.87 €$, or $14.07 €$ and $8.36 €$ per sow and per litter respectively by the end of program implementation. Approximate profit and predicted NPV indicate that the program was created objectively and has shown positive effects. Therefore, many investigators indicate that the economic justification of making breeding stock health control programs primarily depends on an objective approach to the quantification of inputs and outputs and only if expected benefit is larger than expenses the program should be implemented (Thrusfield, 1995; Horst et al., 1999; Rushton et al., 1999; Tešić et al. 2003).

\section{CONCLUSION}

After presence of $L$. interrogans on a pig farm was established and consequent economic losses were measured, consistent leptospirosis eradication program was created. CBA was used during program creation, and the time horizon for program implementation was five years. After this period the number of abortions was reduced about 3.5 times and piglet losses were reduced by one piglet per litter. The achieved benefit was $20218.87 €$, or $14.07 €$ and $8.36 €$ per sow and per litter, respectively.

Address for correspondence:

Dr Milan Tešić

Department of Economics and Statistics,

Faculty of Veterinary Medicine,

Bul. JNA 18, 11000 Belgrade, Serbia\&Montenegro

E-mail: mtesic@vet.bg.ac.yu

\section{REFERENCES}

1. Boqvist S, Chau BL, Gunnarsson A, Olsson Enqvall E, Vagsholm I, Magunsson U, 2002, Animal and herd level risk factors for leptospiral seropositivity among sows in the Mekong delta Vietnam, Prev Vet Med, 53, 233-45.

2. Clark EG, Theede DA, Yong CW, 1980, The pathologic diagnosis of subclinical leptospirosis in Saskatchewan swine, In: Proceeding of the second International Symposium of Veterinary laboratory Diagnosticians, Lucerne, Switzerland, June 24-26, Vol. I, 145-8.

3. Djordjević M, 1987, Tablice složenog interesa, Naučna knjiga, Beograd. 
4. Galić M, 1967, Prilog poznavanju leptospiroze svinja u Vojvodini za period od 1961. do 1966. godine, Doktorska disertacija,Veterinarski fakultet, Zagreb.

5. Harrington RJ, 1975, Leptospiral antibodies in serum from cattle, swine, horses, deer, sheep and goats 1973. and 1974, Amer J Vet Res, 36, 1367-70.

6. Higgins R, Cayourette P, 1977, Serological diagnosis of leptospirosis in the province of Quebec, Can Vet J, 19, 13-6.

7. Horst HS, Vos CJ, Tomassen FHM, Stelwagen J, 1999, The economics evaluation of control and eradication of epidemic livestock diseases, Rev Sci Tech OIE, 18, 367-79.

8. Hudson DB, 1978, Leptospirosis of Domestic Animals, University of Nebraska, Lincoln, USA.

9. Hurne RB, Dijkhuizen AA, 1997, Basic methods of economics analysis, In Dijkhuizen AA, Moris RS, editors, Animal Health Economics - principles and applications, University of Sydney, Australia.

10. Kariv R, Klemfner R, Barnea A, Sidi Y, Schwartz E, 2001, The Changing Epidemiology of Leptospirosis in Israel, Emerging Inf Dis, 7, 990-2.

11. Zakon o zaštiti životinja od zaraznih bolesti koje ugrožavaju celu zemlju, 1986, Službeni list SFRJ 43/86, 6/88, 53/91.

12. Marjanov M, Dujin T, 1969, Periodičnost pojave enzootije pozitivnih reagenata kod leptospiroze i ekonomski gubici tokom godine, Veterinarski glasnik, 23, 34-44.

13. Marjanov M, 1970, Praktična iskustva stečena desetogodišnjim ispitivanjem leptospiroznog zapata krmača. Veterinarski glasnik, 24, 705-10.

14. Office International des Epizooties, 1996, Leptospirosis. In: Manual of Standards for Diagnostic Test and Vaccines, World orgnaization for animal health part 3, sec. 3.1, 198-205.

15. Popović $M$, Galić $M$, 1979, Infekcija svinja leptospirama i mogući poremećaji u reprodukciji, Veterinarski glasnik, 33, 1, 105-8.

16. Rogožarski D, Miloradović S, Stokić S, 1994, Naša Iskustva u lečenju leptospiroze na farmi svinja, Veterinarski glasnik, 48, 9, 727-31.

17. Rushton J, Thornton PK, Otee MJ, 1999, Methods of economics impact assessment, Rev Sci Tech OIE, 18, 315-42.

18. Šerkov Š, Halačeva $M$, Kararizova $L J$, 1976, Vrhu epizootologijate na leptospirozate v promišlenite svinevni kompleksi v Bulgarian, Vet med Nauki, 13, 8, 68-74.

19. Tešić $M, 1995$, Ekonomika i organizacija stočarske proizvodnje i zdravstvene zaštite, Fakultet veterinarske medicine, Beograd.

20. Tešić M, Žugić G, Ignjatović R, 2002, Appling the cost-benefit method in making a program for the eradication of leptospirosis on a pig farm. Proceedings $17^{\text {th }}$ International Pig Veterinary Society, lowa, 368, USA.

21. Tešić M, Tajdić N, Pejin I, Žugić G, Mirilović M, Blagojević M, 2003a, Animal Health Control and the importance of Veterinary Service in Enhancing and Developing livestock Production, Proceedings "Agriculture and Rural Development in European Integration", Faculty of Agriculture, 468-73, Belgrade.

22. Tešić M, Žugić G, Kljajić R, Blagojević M, 2003, Leptospirosis on a pig farm - health and economics significance and creation of eradication program, Proceedings of the Eleventh international Symposium on Veterinary Epidemilogy and Economics, Vina del Mar, novembar 17-21, Chile.

23. Thrusfield M, 1995, Veterinary Epidemiology, Second edition, Blackwell Science, Oxford.

24. Trifunović Ž, 1982, Prilog poznavanju raširenosti leptospiroze kod svinja u nekim oblastima Srbije u odnosu na izvesne ekološke faktore, Doktorska disertacija, Veterinarski fakultet, Beograd.

25. Vićentijević Č, 1964, Leptospiroza svinja u Srbiji, Veterinarski glasnik, 18, 189-92.

26. Vukićević O, 1995, Correlation between leptospirosis in the human population and myomorphous mammals in the Belgrade area, Masters Thesis, Faculty of Biology, Belgrade.

27. Webster JP, Ellis WA, Mac Donald DW, 1995, Prevalence of leptospira spp. In wild brown rats (Rattus norvegicus) on UK farms, Epidem Infect, 114, 195-201.

28. Zaharija I, Todorović Lj, 1964, Istraživanje leptospiroze u domaćih životinja u Banatu, II. Prilog poznavanju leptospiroze svinja, Veterinarski arhiv, 34, 176-82. 
29. Zamora J, Kruze J, Reidemann S, 1976, Leptospirosis de los animales domesticos en el sur de Chile, Vet Bull, 46, 6, 408.

30. Žugić G, 2000, Quantification of economics losses and program of measures for eradication of pig leptospirosis in intensive farming, Masters thesis, Faculty of Veterinary Medicine, Belgrade.

\title{
KONTROLA LEPTOSPIROZE NA FARMI SVINJA SA INTENZIVNIM UZGOJEM
}

\author{
TEŠIĆ M, ŽUGIĆ GORDANA, KLJAJIĆ R, TAJDIĆ NADA, STOJILJKOVIĆ LJ, \\ BLAGOJEVIĆ M i ROGOŽARSKI D
}

\section{SADRŽAJ}

Leptospiroza svinja kao infektivna bolest dovodi do ozbiljnih zdravstvenih i ekonomskiih problema u razvoju svinjarstva. Bolest izaziva bakterija iz roda Leptospira koja ima preko 250 serotipova i dijagnostikovana je kod većeg broja životinja i ljudi u skoro svim zemljama sveta. Pojava bolesti na farmi se retko manifestuje u vidu jasno izraženih kliničkih simptoma, a znatno češće u vidu reproduktivnih poremećaja koji se ogledaju u smanjenoj koncepciji krmača i nazimica, povećavanju abortusa i rađanju mrtve i avitalne prasadi. Ispitivanja su izvršena na jednoj državnoj farmi kapaciteta oko 1500 krmača i 30000 tovljenika godišnje. Pregledom krvnih seruma krmača i nazimica ustanovljeno je prisustvo specifičnih antitela serotipa $L$. pomona i $L$. icterohaemorrhagiae kod $29,80 \%$ ispitivanih grla. $\mathrm{Na}$ osnovu detaljne analize ekonomskih šteta primenom cost-benefit analize urađen je program kontrole i eradikacije leptospiroze svinja za period od pet godina. Pri izradi programa definisani su potrebni inputi i autputi, a ocena programa izvršena je na osnovu neto sadašnje vrednosti i odnosa dobiti i troškova. Posle implementacije programa izvršen je serološki pregled krvi i nije utvrdjeno ni jedno pozitivno grlo, a proizvodno ekonomski rezultati su značajno poboljšani. 